\title{
Sten til de vigtigste øjeblikke i livet...
}

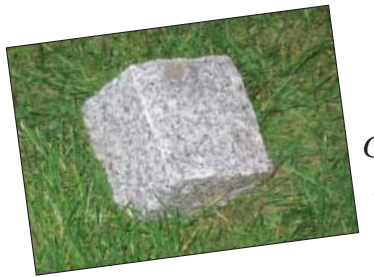

Af geolog Ulla V. Hjuler, GeologiskNyt

Mange af livets vigtigste begivenheder er forbundet med sten - hvem husker ikke diamanten i forlovelsesringen eller det første badeværelse i granit! Derfor må man være ganske omhyggelig med sit valg af sten gennem livet!

Talrige svære beslutninger ligger forude ved livets begyndelse, og det er derfor vigtigt at komme heldigt fra start med det samme!

Den begyndte med en bornholmsk granit Den første hårvask, man rigtigt husker, blev foretaget i en kirke. Allerførste erindring går antageligvis på den dér lange irriterende kjole med kradsende blonder, som man fik presset ned over hovedet, bedst som man slumrede. Kort efter gik det helt galt, da en sortklædt fætter med en paptallerken om halsen pøsede vand i hovedet på én, lige som man atter var faldet i søvn. Her fik man så øje på “badekarret” i romansk stil udført i bornholmsk granit....en formildende kendsgerning på en ellers træls dag!

\section{Kvalitetsvåben - det lønner sig!}

Små to årtier senere er blondekjolen skiftet ud med en elefanthue + det løse. Nu gælder det Ungdomshuset! Udvalget af våben er stort - alligevel falder valget på en solid og relativt billig, lysegrå granitbrosten fra Kina samt lidt bonusskyts i form af en rød, kalifeldspatholdig dobbeltbrosten i Svensk Halmstad-granit! Kom bare an!

\section{Det andet badeværelse}

Efter en årrække har du måske glemt ham med paptallerknen. Men det med badekarret hænger ved! Specielt efter flere slemme år med 70'er-badeværelset i armygrøn plast og med brune fliser på væggene tæt inde på livet... Granitten kalder! Nu skal det grønne helvede og de brune fliser skrottes og udskiftes med en toscansk håndvask nedsænket i en svulstig bornholmsk granitplade, og der skal knaldes Moseløkke granitfliser på væggene!

\section{Til den eneste ene...}

Du har muligvis sagt ja én gang for meget, og det skal traditionen tro følges op med en
God begyndersten til lette kast i praktisk 9x9x9 centimetersformat. (Foto: Forfatteren)

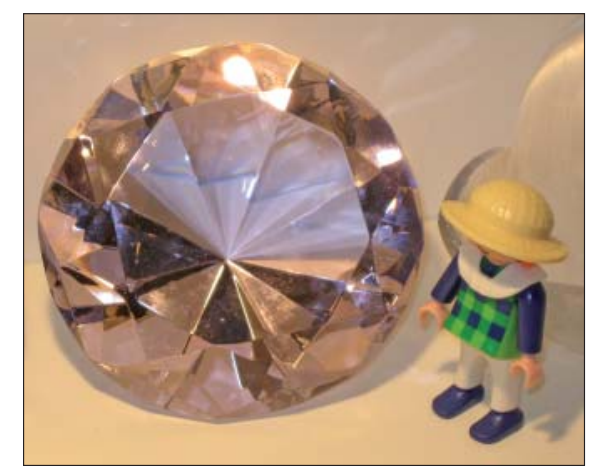

En stort set cegte diamant. (Foto: Forfatteren)

diamantring! Du har nu flere valgmuligheder; du kan tage et smut forbi Tiffany i New York med en meget stor tegnedreng eller alternativt med en meget stor rambuk...

Du kan også støtte din lokale netto - de har nogle glimrende glasimitationer til 29,95, som garanteret vækker lykke, så længe deres sande identitet er ukendt!

\section{Tæt på udløbsdatoen}

Det er efterhånden ved at være nogle årtier siden, at du gav udtryk for din irritation over den første hårvask. Hårvask er ikke rigtigt et tema længere, men ham med paptallerknen vinker så småt ude i det fjerne, og det er ved at være tid til at tænke på, hvilken sten du skal vælge! Den globale opvarmning har nu også fået indflydelse på valget af gravsten, så hvorfor vælge en sandsten eller en marmor, der hurtigt forvitrer med al den sure regn, vi får? Næh, hvis du vil have en sikker død, så vælg en Blå Rønnegranit - det dur!

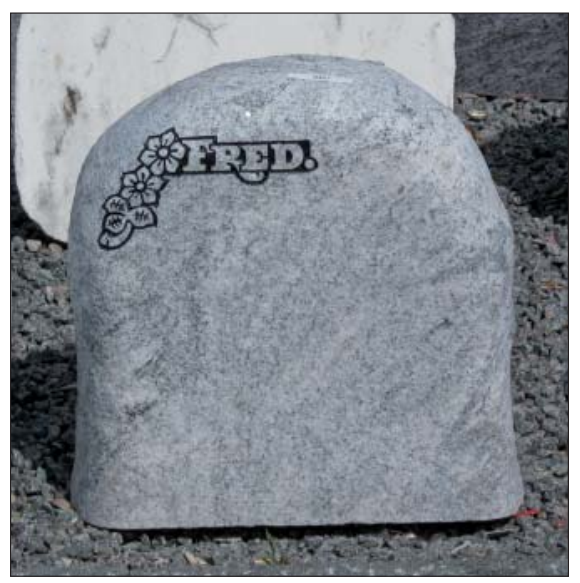

Granit - et sikkert valg! (Foto: Forfatteren) 